\title{
O FOMENTO DO BIOGÁS COMO FONTE DE ENERGIA RENOVÁVEL
}

\section{THE PROMOTION OF BIOGAS AS A SOURCE OF RENEWABLE ENERGY}

\author{
Cristina Alves Rabelo'
}

\begin{abstract}
RESUMO: Sob a análise do desenvolvimento sustentável, a pesquisa tem por objetivo destacar a importância do biogás, como fonte de energia renovável, que pode ser produzido em usinas de recuperaçâo energética e biodigestores, e sua contribuiçâo com a reduçăo de gases de efeito estufa. Foi demonstrado, por meio das Diretivas Europeias, como esta fonte de energia passou ser produzida na Uniăo Europeia, onde as usinas de recuperaçăo energética săo bem avançadas. Enfatizou-se a importância das políticas públicas para o fomento do biogás no Brasil, como o PROINFA e PROBIOGÁS. Ao final, constatou-se a necessária funçăo extrafiscal do tributo, com influência da Economia Comportamental, para as políticas públicas para fomento do biogás, como fonte energética renovável. A metodologia da pesquisa seguiu o método de abordagem dedutivo e a técnica de pesquisa foi a bibliográfica, com consulta a sites especializados.
\end{abstract}

Palavras-chave:Energiarenovável.Biogás.Políticaspúblicas.Economiacomportamental. Incentivos tributários.

ABSTRACT: Under the analysis of sustainable development, the research aims to highlight the importance of biogas, as a renewable energy source, which can be produced in energy recovery plants and biodigesters, and its contribution to the reduction of greenhouse gases. It was demonstrated, through the European Directives, how this energy source started to be produced in the European Union, where the energy recovery plants are well advanced. The importance of public policies for the promotion of biogas in Brazil, such as PROINFA and PROBIOGAS, was emphasized. In the end, the necessary extra-fiscal function of the tax, with the influence of the Behavioral Economy, for public policies to promote biogas as a renewable energy source was found. The research methodology followed the deductive approach method and the research technique was bibliographic, with consultation with specialized sites.

Keywords: Renewable energy. Biogas. Public policies. Behaviorial economics. Tax Incentives.

\footnotetext{
1 Mestranda do Programa de Pós-Graduaçâo em Direito da Pontifícia Universidade Católica do Paraná, PósGraduada em Direito Socioambiental pela Pontifícia Universidade Católica do Paraná e Direito Civil e Direito Processual Civil pela Associaçăo Catarinense de Ensino. Graduada em Direito pela Universidade Federal do Rio de Janeiro. Professora da Escola de Direito do Centro Universitário Católica de Santa Catarina na cidade de Joinville. Advogada. cristina.rabelo@catolicasc.org.br
} 


\section{INTRODUÇÃO}

O estudo foi iniciado a partir da ótica do desenvolvimento sustentável, que implica em atender as necessidades das presentes geraçôes, sem comprometer a possibilidade de as geraçōes futuras satisfazerem suas próprias necessidades. 0 desenvolvimento econômico deve se dar, concomitantemente, ao desenvolvimento ambiental e social.

A energia tem um papel fundamental no desenvolvimento sustentável das naçôes e a pesquisa propóe o necessário fomento do biogás como fonte de energia renovável, pois reduz impactos ambientais negativos, como a diminuiçáo de gases de efeito estufa, provocadores do aquecimento global, como reduçăo de resíduos e de efluentes.

O fomento desta fonte de energia se encontra em nível avançado na Uniăo Europeia, que, por meio de suas Diretivas, diminuiu o número de aterros e, em substituiçăo, construiu usinas de recuperaçâo energética waste to energy.

A grande produçâo de resíduos no Brasil é um grave problema que pode ser resolvido pela recuperaçâo energética de resíduos. No Brasil, já foram desenvolvidas algumas políticas públicas, como o PROINFA e a realizaçăo do PROBIOGÁS.

A pesquisa investiga se a destinaçăo final ambientalmente adequada de resíduos, por meio da recuperaçăo energética, pode ser desenvolvida, por políticas públicas, como incentivos fiscais. A extrafiscalidade, uma das funçôes do tributo, aliada a Economia Comportamental, se direciona a contribuir para o fomento do biogás.

\section{ENERGIA RENOVÁVEL}

Considerando crescente demanda econômica internacional, o fomento de novas fontes de energia renováveis é necessário para o alcance do desenvolvimento econômico sustentável, em virtude das alteraçōes climáticas, escassez de recursos e impactos ambientais negativos.

O conceito de desenvolvimento sustentável foi estabelecido no Relatório Brundtland, em 1987, como "aquele que atende às necessidades dos presentes sem comprometer a possibilidade de as geraçóes futuras satisfazerem suas próprias necessidades" (COMISSĀO MUNDIAL SOBRE O MEIO AMBIENTE E DESENVOLVIMENTO, 1991, p. 46).

No tocante a legislaçăo brasileira, a Constituiçăo da República, em seu artigo 225, caput, contém o conceito de desenvolvimento sustentável e aliado ao artigo 170, caput e inciso VI, se verifica que o desenvolvimento econômico deve se pautar pela preservaçăo do meio ambiente (BRASIL, 1988).

O desenvolvimento econômico da sociedade moderna e a boa qualidade de vida estăo interligados ao fornecimento eficiente de energia. Em face da escassez das fontes convencionais de energia, isto é, ligadas aos combustíveis fosseis, como petróleo, carvâo, gás natural e urânio, fontes renováveis estâo sendo desenvolvidas, como o biogás provenientes de resíduos.

O biogás, composto por gás metano, representa uma importante fonte alternativa de geraçăo de energia, pois diminui a quantidade de resíduos, de efluentes, e gases de efeito estufa deixam de ser lançados na atmosfera (GOLDEMBERG; COELHO; PECORA, 
2008). O efeito estufa é o efeito dos gases na atmosfera, que aprisiona o calor do planeta em vez de deixa-lo escapar para o espaço, sendo o gás metano, componente do biogás, o mais influente (INSTITUTO ASCENDE BRASIL, 2012).

A destinaçáo de resíduos sólidos no Brasil se apresenta como um problema para a qualidade de vida e para a gestâo ambientalmente adequada. No último panorama traçado pela Associaçăo Brasileira de Empresas de Limpeza Pública e Resíduos Especiais (Abrelpe), o montante de resíduos sólidos urbanos em 2017, coletados no Brasil pelo sistema de saneamento básico municipal, foi de 71, 6 milhóes de toneladas, com um índice de cobertura de coleta de $91,2 \%$ para todo o território, verificando-se que 6,9 milhôes de toneladas de resíduos nâo foram coletados, portanto tiveram destinaçâo imprópria (ABRELPE, 2017).

Em relaçâo à disposiçâo final dos resíduos sólidos urbanos em 2017 em todo o território nacional, 59,1\% foram dispostos em aterros sanitários e 40,9\% foram despejados em locais inadequados por 3.352 municípios em lixóes e aterros controlados (ABRELPE, 2017).

Atualmente, um dos desafios do Brasil é a eliminaçăo dos lixōes, quando há disposiçăo de resíduos a céu aberto, sem nenhum tratamento, e aterros controlados, pois causam consequências danosas ao meio ambiente, como poluiçâo do solo com o chorume, poluiçăo das águas, quando se atingem os lençóis freáticos e mesmo poluiçăo do ar, podendo provocar doenças na populaçăo existente em seu entorno (BLEY, 2015). O chorume é um resíduo líquido com grande quantidade de carga orgânica e forte coloraçâo, produzido por decomposiçâo química e microbiológica dos resíduos sólidos alocados em aterro (MORAIS; SIRTORI; PERALTA-ZAMORA, 2006).

A transformaçăo de resíduos em biogás, para utilizaçăo como fonte energética, pode se realizar em aterros sanitários, usinas de recuperaçăo energética ou biodigestores. A Política Nacional de Resíduos Sólidos, instituída pela Lei n. 12.305, de 2 de agosto de 2010 , em seus artigos $3^{\circ}$, inciso VII e $9^{\circ}$, determina observar a seguinte ordem de prioridade: năo geraçâo, reduçăo, reutilizaçăo, reciclagem, tratamento dos resíduos sólidos e disposiçăo final ambientalmente adequada dos rejeitos, na gestăo e gerenciamento dos resíduos sólidos. (BRASIL, 2010). A disposiçăo ambientalmente adequada pode beneficiar a produçấo de biogás, para a produçăo de energia. Apesar da lei prever que a disposiçăo em aterros é ambientalmente adequada, nâo deve ser considerado, pois produz efeitos danosos ao meio ambiente, por exemplo o chorume pode poluir os lençóis freáticos.

Segundo a Associaçâo Brasileira de Biogás e Biometano (Abiogás) informa que o biogás tem um enorme potencial para compor a matriz energética brasileira sustentável. O potencial teórico total é de 80 milhōes de metros cúbicos por dia, equivalente a $24 \%$ da demanda de energia elétrica ou $44 \%$ da demanda de óleo diesel. 0 maior potencial de geraçăo está no setor sucroenergético, que corresponde a 70\% deste total (MINISTÉRIO DO MEIO AMBIENTE, ABIOGÁS, 2018).

Os principais substratos em escala comercial brasileira para gerar biogás săo: parcela orgânica dos resíduos sólidos urbanos, rejeitos da produçăo de açúcar e etanol da cana de açúcar, como vinhaça e torta de filtro, e dejetos de criaçâo suína. Também săo utilizados, mas em menor número: resíduos da produçăo de alimentos em geral, descarte de restaurantes, grama, dejetos das criaçôes bovina e avícola, e efluentes sanitários (BRASIL, EPE, 2018). 
Em meados dos anos 90, a Uniâo Europeia começou a reconhecer o impacto potencial da gestâo dos resíduos sólidos nas alteraçóes climáticas, colocando metas para o desvio destes resíduos dos aterros sanitários, o que impulsionou a criaçăo de usinas de geraçăo de energia elétrica a partir dos resíduos (INGLATERRA, 2014).

Os aterros deveriam ter por objetivo proteger as águas superficiais e os lençóis freáticos, como reduzir gases de efeito estufa lançados para atmosfera, sendo mais adequados do que os lixôes, porém no mundo há apenas $20 \%$ de aterros nestes moldes (THEMELIS, BARRIGA, ESTEVEZ, 2013). Além disso, os aterros apresentam algumas desvantagens, como a falta de espaço para aterramento, o reduzido ciclo de vida dos aterros e a necessidade de remediaçáo no encerramento de aterros (POLETTO FILHO, POLETO, 2017).

As tecnologias para recuperaçăo energética de resíduos, conhecidas como waste to energy, mais utilizadas săo: incineraçáo mass burning, mechanical biological treatment, gaseificaçăo e pirólise (ABRELPE E PLASTIVIDA, 2012). Essas tecnologias de recuperaçăo energética de resíduos provocam baixos impactos ambientais e reduzem as externalidades ambientais, que seriam causadas caso năo fossem implantadas.

A Diretiva Europeia 1999/31/CE trouxe contribuiçôes para a destinaçâo adequada de resíduos sólidos, sob a orientaçâo da necessidade de serem tomadas medidas para reduzir a produçâo de gás metano proveniente dos aterros, diminuindo a deposiçấo de resíduos biodegradáveis em aterros, para, consequentemente, diminuir o aquecimento global. Esta diretiva contém metas progressivas para reduçăo da disposiçâo de matéria orgânica, biodegradável nos aterros sanitários. Os aterros podem apresentar perigo para o meio ambiente, e os efeitos danosos poderâo ser atribuídos ao operador do aterro (UNIÂO EUROPÉIA, 1999).

Após, houve a ediçăo da Diretiva 2008/98/EC, que disciplinou a hierarquia de disposiçâao de resíduos na Uniăo Europeia, e reduziu a emissăo de gases de efeito estufa proveniente da eliminaçăo de resíduos em aterro, para nâo causar impactos negativos ao meio ambiente e nem a saúde humana. A hierarquia constitui em uma ordem de prioridades de disposiçâo de resíduos, que tem como sequência: (I) prevençâo e reduçâo; (II) preparaçăo para reutilizaçấo; (III) reciclagem; (IV) outros tipos de valorizaçăo, como, por exemplo, a valorizaçấo energética; e, (V) eliminaçăo, sendo que os aterros devem ser evitados ao máximo nessa ordem de prioridades, assim como náo se deve apoiar a incineraçấo de materiais recicláveis (UNIÂO EUROPÉIA, 2008).

Foi a partir da Diretiva 2000/76/CE (UNIÂO EUROPÉIA, 2000), que posteriormente foi reformulada pela Diretiva de Emissōes Industriais 2010/75/EU (UNIÂO EUROPÉIA, 2010), as plantas Waste to Energy (WTE) passaram a cumprir os rigorosos padróes de emissăo de gases na atmosfera, por meio de monitoramento, recepçăo de resíduos e tratamento. Com o aumento da tipping fee dos aterros e fiscalizaçăo forte, houve um incentivo para construçăo de usinas WTE na Europa, e concomitantemente, a disposiçăo de resíduos em aterros sanitários, obrigatoriamente, passou a ser acompanhada com a captaçâo de metano, queimado no flare, para a produçâo de energia elétrica ou como biogás em processos industriais e veículos, sendo proibida a sua emissăo direta na atmosfera. No ano de 2017, a Uniâo Europeia registrou 47\% dos resíduos sólidos foram destinados à reciclagem e à compostagem, 28\% destinados como insumo para usinas WTE e apenas 24\% foram depositados em aterros sanitários (CEWEP, 2018). 
Nas últimas décadas, muitos países europeus experimentaram uma tendência positiva no chamado processo de dissociaçăo, quando se verifica que uma economia é capaz de crescer sem sobrecarregar o meio ambiente. É reflexo da diminuiçâo de geraçâo de resíduos, como também da menor utilizaçăo de aterros sanitários na Europa, o que se constitui um exemplo a seguir pelos outros países (STEHLIK, 2016).

No Brasil, está sendo implantada uma unidade de recuperaçăo energética em Barueri, no Estado de Sáo Paulo, por parceria pública privada, pelo período de trinta anos, cujo o vencedor da licitaçâo foi o Consórcio FOXX (HAZTEC, 2019). A usina waste to energy possui capacidade de gerar energia elétrica de $20 \mathrm{MW}$, pode tratar de 825 toneladas/dia. Os resíduos săo coletados dos municípios da regiăo metropolitana do Estado de Sáo Paulo: Barueri, Carapicuíba e Santana do Parnaíba. A usina tem previsăo para funcionar 8.000 horas por ano (SOARES; COELHO; 2019).

No Estado do Paraná, existe a CSBionergia, que é formada pela Companhia de Saneamento do Paraná (Sanepar) e pelo Grupo Cattalini Bio Energia, que explora resíduos orgânicos e lodo de esgoto e transforma em energia, pela tecnologia de biodigestâo (ÉPOCA, 2018).

Há previsăo para 2021 para implantaçáo e funcionamento da Usina Bonfim do Grupo Raízen, a partir dos substratos vinhaça e torta de filtro (subprodutos da cana de açúcar), que iniciará a participaçâo deste setor no mercado regulado de energia em Sáo Paulo, após participar de leilâo A-5/2016. Por mercado regulado de energia entende-se por segmento do mercado que se desenvolve por operaçôes de compra e venda de energia entre agentes vendedores e agentes distribuidores, antecedido de licitaçâo, salvo os casos previstos em lei. Ao passo que mercado livre de energia é a parcela do mercado que compra e vende energia elétrica e se baseia em contratos bilaterais. Um dos benefícios de participar do mercado regulado é a vigência por 25 anos do contrato, que corresponde garantia do financiamento (CADERNOS FGV ENERGIA, 2017).

Apesar destes três exemplos, ainda sâo poucos e necessitam de fomento. A participaçáo da biomassa proveniente de resíduos sólidos ainda possui pequena participaçâo na matriz energética brasileira, que é composta em maior quantidade pela hidroeletricidade, mas sua produçáo pode ser intensificada por meio de políticas públicas e incentivos.

\section{POLÍTICAS PÚBLICAS VOLTADAS AO BIOGÁS}

As políticas públicas săo o conjunto de açōes, metas, e planos, que os governos nacionais, estaduais ou municipais traçam para atingir o bem-estar da sociedade e o interesse público (CALDAS, 2008). Podem também ser consideradas como um conjunto de processos para atingir uma escolha racional e coletiva de prioridades. $O$ conjunto de processos sáo aqueles procedimentos coordenados pelo governo com a interaçăo entre os sujeitos e entre estes e a Administraçâo (BUCCI, 2002).

O fornecimento de energia de forma eficiente para a populaçăo, implicando no fomento de novas fontes de energias renováveis, como a proveniente dos resíduos, se constitui em uma prioridade estatal.

A Política Nacional Energética prevê como um de seus objetivos, artigo $1^{\circ}$, inciso 
VIII, utilizar fontes alternativas de energia, mediante o aproveitamento econômico dos insumos disponíveis e das tecnologias aplicáveis, assim como no inciso XIV, incentivar a geraçâo de energia elétrica a partir da biomassa e de subprodutos da produçâo de biocombustíveis, em razâo de seu caráter limpo, renovável e complementar à fonte hidráulica (BRASIL, 1997).

Uma iniciativa pública relevante foi o Programa de Incentivo às Fontes Renováveis (PROINFA), que foi criado pela Lei n 10.438, de 26 de abril de 2002 (BRASIL, 2002) e em seu artigo $3^{\circ}$, define seu objetivo como o aumento na participaçáo de energia elétrica produzida por produtores independentes autônomos, através de empreendimentos com base em fontes eólicas, pequenas centrais hidrelétricas e biomassa, no Sistema Elétrico Interligado Nacional.

Produtor independente autônomo é definido pelo $\S 1^{\circ}$ do artigo $3^{\circ}$ da Lei n. 10.438 , de 2002, como pessoa jurídica năo detentora de concessấo ou sob controle de concessionária ((BRASIL, 2002).

O Programa de Incentivo às Fontes Alternativas de Energia Elétrica (PROINFA) instituído em 2002, e regulamentado pelo Decreto n. 4.541, de 23 de dezembro de 2002, pode ser considerado uma política pública realizada pelo Estado, voltado às energias alternativas. Incentivou a geraçăo de energia por produtores independentes autônomos, possibilitou o desenvolvimento de energias alternativas e contribuiu para a reduçáo dos gases do efeito estufa (NASCIMENTO NETO, 2017).

OProbiogás é outra iniciativa pública e consistiu em um projeto realizado entre Brasil e Alemanha para o fomento do aproveitamento energético de biogás no Brasil. O objetivo foi para contribuir com a ampliaçăo do uso energético eficiente do biogás no Brasil, e consequentemente reduzir os gases de efeito estufa. Foi feita uma rede de parcerias nas esferas governamental, acadêmica e empresarial e durou de 2013 a 2017 (SECRETARIA NACIONAL DE SANEAMENTO AMBIENTAL, 2015).

Pode-se apontar também a reduçăo de tarifas pela Agência Nacional de Energia Elétrica (ANEEL), a agência reguladora do setor elétrico, para o uso dos sistemas elétricos de transmissáo e de distribuiçấo, excluindo as tarifas aplicadas a determinadas fontes. $O$ resultado da Audiência Pública $n^{\circ}$ 011/2004 implicou em reduçăo de tarifas para sistemas elétricos de transmissăo e de distribuiçăo de fontes renováveis. No tocante a biomassa, a isenção de tarifas seria possível, se utilizasse como insumo energético, no mínimo, 50\% de biomassa composta de resíduos sólidos urbanos e/ou biogás de aterro sanitário, ou biodigestores de resíduos vegetais ou animais, assim como lodos de estaçōes de tratamento de esgoto. A partir deste cenário, projetos energéticos puderam ser desenvolvidos (ABRELPE. ATLAS BRASILEIRO DE EMISSÖES DE GEE E POTENCIAL ENERGÉTICO NA DESTINAÇĀO DE RESÍDUOS SÓLIDOS, 2019).

A política estadual do biogás e do biometano do Estado do Paraná foi criada pela Lei $n^{0} 19.500$, de 21 de maio de 2018, e reúne diretrizes para políticas públicas, a possibilidade de incentivos e o fomento que podem ser adotados pelo Estado (BRASIL, 2018). Como exemplo de incentivo se destaca a isençâo do ICMS no Estado do Paraná, de acordo com a Lei $n^{\circ} 19.595$, de 12 de julho de 2018, incidente sobre a energia elétrica fornecida pela distribuidora à unidade consumidora, na quantidade correspondente à soma da energia elétrica injetada na rede de distribuiçâo pela mesma unidade consumidora com os créditos de energia ativa originados na própria unidade consumidora no mesmo mês, 
em meses anteriores ou em outra unidade consumidora do mesmo titular, nos termos do Sistema de Compensaçâo de Energia Elétrica estabelecido por normas regulamentadoras da Agência Nacional de Energia Elétrica. Em seu § $1^{\circ}$, inciso I, o benefício previsto se aplica somente à compensaçâo de energia elétrica produzida por microgeraçâo e minigeraçăo definidas na Resoluçăo Normativa da Aneel nº 482, de 17 de abril de 2012, ou enunciado normativo que a substituir, cuja potência instalada seja, respectivamente, menor ou igual a $75 \mathrm{KW}$ (setenta e cinco quilowatts) e superior a $75 \mathrm{KW}$ (setenta e cinco quilowatts) e menor ou igual a 1MW (um megawatt) (BRASIL, 2018).

As escolhas governamentais para adoçăo de políticas públicas, voltadas ao fomento do biogás, como incentivos tributários, podem se utilizar das premissas da economia comportamental, pois o ser humano năo age sempre com base no custo e benefício, mas também com base em limitaçôes cognitivas e vieses. A funçâo extrafiscal dos tributos serviria para desonerar o que menos polui, induzindo o comportamento dos agentes públicos.

\section{FOMENTO DO BIOGÁS TENDO POR PARÂMENTRO A ECONOMIA COMPORTAMENTAL}

A Economia Comportamental surgiu na década de 70, do século passado, como resposta a racionalidade econômica, base teórica da Escola Neoclássica da Economia (RIBEIRO, 2016).

A segunda fase da Teoria Econômica Neoclássica está relacionada a "Revoluçâo Marginalista", tendo como base a Teoria da Utilidade, indicando que o valor de um bem é formado pelo trabalho (custo), mas também pela utilidade marginal que o indivíduo espera obter das escolhas realizadas. Se originam as primeiras representaçóes de curvas de oferta (lado dos custos) e curvas de demanda (lado da utilidade) para apontar os preços de mercado.

No começo do século XX, a Teoria da Utilidade năo estava sendo mais aceita para explicar as escolhas humanas, pois tinham motivaçóes psicológicas e năo podiam ser explicadas por funçōes matemáticas, segundo a Economia Comportamental. A quantidade e a procura de determinados bens, ou a adoçâo de algum incentivo econômico, sâo influenciadas por uma série de variáveis que năo se restringe à simples análise dos preços, como também por motivaçóes psicológicas, o que implica em resultados bons ou ruins.

Segundo a Economia Comportamental, as pessoas săo limitadamente racionais, pois suas escolhas sâo feitas, de acordo como săo apresentadas, como depende de sua disposiçăo de correr riscos em um ambiente de incertezas. As escolhas săo limitadas, porque preferem o status quo, o apego a situaçâo presente, podendo ser escolhas ruins, muitas vezes evitadas, com base nos incentivos, aos quais os agentes econômicos estăo expostos. Por esta razăo, a Economia Comportamental tem seu papel fundamental em políticas públicas, para evitar decisóes ineficientes (RIBEIRO, DOMINGUES, 2018).

Exemplo de incentivo para o agente econômico sâo os tributos ambientais, que têm a finalidade específica em destinar sua arrecadaçâo à proteçâo do meio ambiente. Através de instrumentos tributários, é possível conciliar crescimento econômico e proteçăo ambiental. 
O tributo surge como instrumento eficiente tanto para proporcionar recursos ao Estado em seu poder agir (tributaçâo fiscal), como para estimular condutas náo poluidoras e desestimular as poluidoras (tributaçâo extrafiscal).

Aponta Ricci, que o tributo possui funçâo fiscal, parafiscal e extrafiscal. A funçâo fiscal está relacionada à arrecadaçăo de numerário para os cofres públicos estatais. A parafiscal significa contribuir ao erário da Administraçăo Pública indireta ou paraestatal para que cumpram a sua finalidade. A extrafiscal é diversa da arrecadatória (RICCI, FOLLONI, 2014).

Segundo Hugo de Brito Machado Segundo, estudos recentes da neurociência e da economia comportamental resgatam a ideia de que o ser humano nâo age sempre como homo economicus, em virtudes de fatores que interferem em suas decisôes, como custo e benefício, mas também com limitaçōes cognitivas e vieses. Na seara ambiental, com base na extrafiscalidade, os tributos serviriam para desonerar o que menos polui, induzindo o comportamento dos agentes (SEGUNDO, 2018).

Verifica-se pelo artigo 170, caput, e inciso VI, da Constituiçăo Federal de 1988 (BRASIL, 1988), que o crescimento econômico e social brasileiro deve se concretizar concomitantemente à defesa do meio ambiente. Por sua vez, o artigo 225 do mesmo diploma constitucional destaca que é dever de todos preservar o meio ambiente sadio para as presentes e futuras geraçôes. O fomento do biogás como fonte de energia renovável, como visto, é benéfico ao meio ambiente ecologicamente equilibrado, pois reduz a quantidade de resíduos, evita produçâo de chorume e contaminaçấo de lençóis freáticos, e reduz gases de efeito estufa.

Porém, nâo sâo encontradas normas tributárias constitucionais, que objetivam a proteçâo ao meio ambiente, deixando a normatizaçâo a critério do legislador infraconstitucional. Podem ser citados dispositivos constitucionais, que possuem conteúdo extrafiscal tributário, como os artigos $153, \S 3^{\circ}$, I e $\S 4^{\circ}$, I; artigo $155, \S 2^{\circ}$, III e $\S 6^{\circ}$, II, mas năo possuem conteúdo ambiental, deixando a critério do legislador infraconstitucional a normatizaçăo sobre a proteçăo do equilíbrio ecológico.

De acordo com o entendimento de Blanchet e Oliveira, as normas constitucionais tributárias sâo importantes para desestimular condutas mais agressivas ao meio ambiente, citando como exemplo diferentes hipóteses de incidências tributárias, como em combustíveis fósseis e biocombustíveis; para promover atividades empresariais que tenham menor emissăo de gases poluentes, como o gás carbônico (CO2), podendo estarem previstas na norma constitucional (BLANCHET, OLIVEIRA, 2014).

Como afirma Costa, os países mais desenvolvidos, como a França, a Alemanha e os Estados Unidos da América, se preocupam em introduzir um eficiente sistema de tributos ambientais, pois estimula o comportamento individual, que espontaneamente preserva o meio ambiente, para evitar tributaçăo mais gravosa (COSTA, 2011).

Yazbek sustenta que na esfera ambiental, a intervençâo do Estado pode se dar em dois mecanismos distintos: induçâo e direçâo. Os mecanismos de direçăo correspondem as normas proibitivas, que envolvem fiscalizaçâo, aplicaçâo de sançôes sobre infratores e de imposiçấo de dever de reparaçấo do dano. Os mecanismos de induçăo năo sâo coercitivos e buscam direcionar o comportamento de agentes econômicos, com estímulos, se estiverem na linha de conduta pretendida pelo Estado (YAZBEK, FOLLONI, 2014). 
Incentivos financeiros poderiam ser concedidos aos agentes de geraçăo de energia elétrica de usinas de recuperaçâo energética waste to energy, como a desoneraçâo fiscal, ainda que temporária, do Imposto sobre Circulaçăo de Mercadorias e Serviços de Transporte Interestadual ou Intermunicipal e de Comunicaçăo (ICMS), Programas de Integraçăo Social e de Formaçâo do Patrimônio do Servidor Público (PIS/PASEP) e Contribuiçăo Social para o Financiamento da Seguridade Social (COFINS), na modalidade de produtor independente de energia. Este último consiste em pessoa jurídica ou empresas reunidas em consórcio, que recebe concessâo ou autorizaçâo do Poder Concedente para produzir energia elétrica destinada ao comércio de toda ou parte da energia que será produzida, podendo participar do ambiente de contrataçấo regulado ou ambiente de contrataçấo livre de energia. No ambiente regulado, o produtor pode participar de licitaçăo, na modalidade leilăo, onde encontra a concorrência de outras fontes renováveis de energia, como a eólica e a solar, com mais tradiçâo no mercado, sendo, portanto, necessária o incentivo tributário para que possa se desenvolver.

Um incentivo já existente é a reduçâo nâo inferior a 50\% (cinquenta por cento) aplicada nas tarifas de uso dos sistemas elétricos de transmissăo e distribuiçấo (TUSD e TUST), para os empreendimentos de geraçăo de energia proveniente de resíduos sólidos urbanos e rurais, cuja potência injetada nos sistemas de transmissâo e distribuiçáo seja menor ou igual a $30.000 \mathrm{KW}$ de potência instalada, com incidência na produçâo e no consumo da energia comercializada ou destinada à autoproduçăo, de acordo com o artigo 26, $\S 1^{\circ}$, incisos I e II da Lei nº 9.427/1996. (BRASIL, 1996).

Por isso os instrumentos econômico-financeiros devem ser adequados aos princípios tributários e legislaçâo ambiental, como opçôes eficazes do dever de proteçáo ambiental pelos particulares.

Assim, o Governo Brasileiro pode, por meio de escolhas públicas corretas, com base em prioridades, incentivar a inovaçâo tecnológica para a diversificaçâo da sua matriz energética, com a inclusâo de fontes de baixa emissăo de carbono, como o biogás, com o auxílio da extrafiscalidade.

\section{CONSIDERAÇÕES FINAIS}

A partir do estudo desenvolvido com enfoque no fomento do biogás, como fonte de energia renovável, pode-se verificar que, no Brasil, seria muito útil, para destinar ambientalmente os resíduos, sem provocar graves impactos ambientais, e ainda reduziria os gases de efeito estufa. Deste modo, contribuiria com o desenvolvimento sustentável, que busca o equilíbrio entre as esferas econômica, ambiental e social.

Algumas políticas públicas já foram desenvolvidas em território nacional, como o PROINFA, o PROBIOGÁS, a Lei n ${ }^{\circ}$ 19.500, de 21 de maio de 2018, da Política Estadual do Biogás e do Biometano do Estado do Paraná, que impulsionaram o fomento do biogás.

Outras políticas públicas podem ser criadas, como aquelas, ligadas a incentivos fiscais, como, por exemplo, desoneraçăo fiscal, ainda que temporária, do Imposto sobre Circulaçấo de Mercadorias e Serviços de Transporte Interestadual ou Intermunicipal e de Comunicaçâo (ICMS), Programas de Integraçâo Social e de Formaçâo do Patrimônio do Servidor Público (PIS/PASEP) e Contribuiçăo Social para o Financiamento da 
Seguridade Social (COFINS), na modalidade de produtor independente de energia.

Os incentivos fiscais estăo relacionados à extrafiscalidade, que pode implicar em reduçăo ou o aumento dos tributos, e influenciam condutas que se deseja estimular ou desestimular. Tem por objetivo influenciar os comportamentos dos agentes, para que hajam resultados positivos.

Segundo a economia comportamental, todavia, estímulos e desestímulos econômicos nem sempre funcionam, e às vezes têm efeito inverso ao pretendido. Nâo quer dizer que năo devam ser concedidos, mas devem ser bem planejados e de acordo com as prioridades e, no caso do biogás, com preservaçăo ambiental.

O Estado tem o dever de assegurar a todos existência digna e o desenvolvimento econômico deve ser concomitante a preservaçáo ambiental, para garantir um ambiente sadio para as presentes e futuras geraçôes.

\section{REFERÊNCIAS}

ABRELPE. Panorama dos Resíduos Sólidos no Brasil, 2017. Consulta disponível em http:// abrelpe.org.br/pdfs/panorama/panorama_abrelpe_2017.pdf Acesso em 27 de jul. 2019;

ABRELPE. Atlas Brasileiro de Emissōes de GEE e Potencial Energético na Destinaçăo de Resíduos Sólidos. Disponível em: < http://abrelpe.org.br/atlas-brasileiro/>, p. 95. Acesso em 26 de jul. 2019;

ABRELPE e PLASTIVIDA. Caderno Informativo Recuperaçăo Energética de Resíduos Sólidos Urbanos. 2012. Disponível em: 〈http://abrelpe.org.br/download-caderno/>. Acesso em 31 de jul. 2019.

BLANCHET, Luiz Alberto e OLIVEIRA, Edson Luciani. Tributaçăo da Energia no Brasil: necessidade de uma preocupaçăo constitucional extrafiscal e ambiental. Sequência (Florianópolis), n. 68, p. 159-187, jun. 2014;

BLEY JR., Cícero. Biogás: A energia invisível. CIBiogás-ER, n. 12232131, 2015, p. 48-50.

BRASIL. Declaraçăo da Conferência de ONU no Ambiente Humano (traduçăo livre). Consulta disponível em <http:/?www.mma.gov.br/estruturas/agenda21/_arquivos/ Estocolmo.doc> Acesso em: 27 jul. 2019;

BRASIL. CONSTITUIÇĂO DA REPÚBLICA FEDERATIVA DO BRASIL DE 1988. Disponível em: < http://www.planalto.gov.br/ccivil_03/constituicao/constituicao.htm>. Acesso em 26 de jul. 2019;

BRASIL. Lei n 9.427, de 26 de dezembro de 1996-Publicaçăo original. Disponível em: < http://www.planalto.gov.br/ccivil_03/leis/L9427cons.htm>. Acesso em: 29 fev. 2020.

BRASIL. Lei n. 9.478, de 6 de agosto de 1997- Publicaçăo original. Disponível em: < http:// www.planalto.gov.br/ccivil_03/LEIS/L9478.htm> Acesso em: 04 de out. 2018. 
BRASIL. Lei n. 10.438, de 26 de abril de 2002- Publicaçăo original. Consulta disponível em: <http://www.planalto.gov.br/ccivil_03/leis/2002/L10438.htm〉 Acesso em 27 de jul. 2019;

BRASIL. Lei n. 10.438, de 26 de abril de 2002- Publicaçăo original. Consulta disponível em: 〈http://www.planalto.gov.br/ccivil_03/leis/2002/L10438.htm> Acesso em 27 de jul. 2019.

BRASIL. Lei $\mathbf{n}^{\circ}$ 12.305, de 02 de agosto de 2010. Disponível em:< http://www.planalto. gov.br/ccivil_03/_ato2007-2010/2010/lei/112305.htm>. Acesso em 07 dez. 2019.

BRASIL. Lei n. 9.074, de 07 de julho de 1995- Publicaçăo original. Consulta disponível em: <http://www.planalto.gov.br/ccivil_03/Leis/L9074cons.htm> Acesso em 27 de jul. 2019;

BRASIL. Ministério do Meio Ambiente. ABIOGÁS. Consulta disponível em: http:// www.mme.gov.br/documents/10584/4323103/\%20ABioga\%CC\%81s.pdf/8e80e093-4042-4c24-ad9e-851c6190b399> Acesso em: 07 de out. 2018.

BRASIL. Lei n. 19.595, de 12 de julho de 2018. Disponível em: <http://portal.alep.pr.gov. $\mathrm{br} / \mathrm{modules} / \mathrm{mod}_{-}$legislativo_arquivo/mod_legislativo_arquivo.php?leiCod=51518\&tipo=L\&tplei=0 >. Acesso em 27 de jul. 2019;

BRASIL. Empresa de Pesquisa Energética. Ministério de Minas e Energia. Papel da Biomassa na Expansăo da Energia Elétrica. Estudos de Longo Prazo. Documento de Apoio ao PNE 2050. 2018. Disponível em: 〈http://www.epe.gov.br/sites-pt/publicacoes-dados-abertos/publicacoes/PublicacoesArquivos/publicacao-227/topico-457/ Biomassa\%20e\%20Expans\%C3\%A3o\%20de\%20Energia.pdf>. Acesso em: 15 jan. 2020.

BRASIL. SECRETARIA NACIONAL DE SANEAMENTO AMBIENTAL. Probiogás. Tecnologias de digestăo anaeróbia com relevância para o Brasil: substratos, digestores e uso de biogás/ Probiogás; organizadores: Ministério das Cidades, Deutsche Gesellschaft für Internacionale Zusammenarbeit GmbH (GIZ), autores: Oliver Jende, et al- Brasília, DF; Ministério das Cidades, 2015, 83 p, ISBN: 978-85-7958-039-0;

BUCCI, Maria Paula Dallari. Direito administrativo e políticas públicas. Săo Paulo: Saraiva, 2002;

FUNDAÇĀO GETÚLIO VARGAS, Cadernos FGV Energia. Biocombustíveis. Rio de Janeiro: FGV Energia, agosto de 2017, ano 4, nº 8, p. 100. Consulta disponível em: <https://fgvenergia.fgv.br/sites/fgvenergia.fgv.br/files/caderno_biocombustivel_-_baixa.pdf Acesso em: 07 de out. 2018.

CALDAS, Ricardo Wahrendorff (coord.). Políticas Públicas: conceitos e práticas. Belo Horizonte: Sebrae/MG, Série Políticas Públicas, vol. 7, 2008;

CEWEP. Waste-to-energy: Energising your waste. 2018. Disponível em: <http://www. cewep.eu/wpcontent/uploads/2018/07/Interactive-presentation-2018-New-slides. pdf> Acesso em 15 de out. 2019; 
COMISSĂO MUNDIAL SOBRE O MEIO AMBIENTE E DESENVOLVIMENTO. Nosso Futuro Comum. $2^{a}$ ediçâo. Rio de Janeiro: Fundaçâo Getúlio Vargas, 1991, p.46. Disponível em: < https://edisciplinas.usp.br/pluginfile.php/4245128/mod_resource/content/3/Nosso\%20 Futuro\%20Comum.pdf>. Acesso em 27 de jul. 2019;

COSTA, Regina Helena. Apontamentos sobre a Tributaçăo Ambiental no Brasil. Lusíada. Direito e Ambiente, Lisboa, $n^{\circ}$. 2/3 de 2011;

GOLDEMBERG, José; COELHO, Suani Teixeira; PECORA, Vanessa. Perspectivas da utilizaçăo de biogás como fonte de energia. In: BARROS FILHO, Omar L. de; BOJUNGA, Sylvia (orgs.). Potência Brasil: gás natural, energia limpa para um futuro sustentável, 2008, p. 135-136.

HAZTEC. Disponível em:< http://haztec.com.br/solucoes-ambientais-completas/index. php/solucoes/unidades-de-recuperacao-energetica>. Acesso em 31 de jul. 2019.

INGLATERRA. Department for Enviromental, Food \& Rural Affairs. Energy from waste: a guide to debate. Disponível em: https://assets.publishing.service.gov.uk/government/uploads/system/uploads/attachment_data/file/284612/pb14130-energy-waste-201402.pdf>. Acesso em 15 de out. 2019;

INSTITUTO ACENDE BRASIL. Mudanças Climáticas e o Setor Elétrico Brasileiro, 2012. Disponível em:<http://www.acendebrasil.com.br/media/estudos/2012_hitePaperAcendeBrasil_06_MudancasClimaticas_Rev2.pdf>. Acesso em 27 de jul. 2019;

MORAIS, Josmaria Lopes de; SIRTORI, Carla; PERALTA-ZAMORRA, Patrício G. Tratamento de chorume de aterro sanitário por fotocatálise heterogênea integrada a processo biológico convencional. Disponível em: <http://www.scielo.br/ scielo.php?pid=S0100-40422006000100005\&script=sci_arttext\&tlng=pt> Acesso em: 16 fev. 2020.

NETO, José Osório do Nascimento. Políticas Públicas e Regulaçăo Socioambiental. Curitiba: Editora Íthala, 2017;

POLETTO FILHO, Jose Antonio, POLETTO, Gustavo Cassettari. Incineraçăo com Recuperaçăo Energética, uma Alternativa para Destinaçăo Correta do Resíduo Solido Urbano. 2017. Disponivel em: <https://revista.univem.edu.br/REGRAD/article/ view/2228>. Acesso em 09 mar. 2019.

RIBEIRO, Marcia Carla Pereira; KLEIN, Vinícius (coord.). $\mathbf{O}$ que é análise econômica do direito: uma introduçăo. 2 ed. Belo Horizonte: Fórum, 2016;

RIBEIRO, Márcia Carla Pereira; DOMINGUES, Victor Hugo; KLEIN, Vinícius. Análise econômica do direito: justiça e desenvolvimento. 1 ed. Curitiba: CRV, 2016. 182 p. ISBN 978-85-444-0725-7;

RIBEIRO, Marcia Carla; DOMINGUES, Vitor Hugo. Economia comportamental e direito: a racionalidade em mudança. Revista Brasileira de Políticas Públicas. 2018, v.8, p. 457-472; 
RICCI, Henrique Cavalheiro; FOLLONI, André Parmo. A tributaçăo extrafiscal ambiental e a limitaçăo imposta pela igualdade tributária. 2014. p. 182. Dissertaçâo (Mestrado) Pontifícia Universidade Católica do Paraná, Curitiba, 2014. Disponível em: http://www.biblioteca.pucpr.br/tede/tde_busca/arquivo.php?codArquivo=2703 Acesso em 22 de jul 2018;

SEGUNDO, Hugo de Brito Machado. Ciência do direito tributário, economia comportamental e extrafiscalidade. Revista Brasileira de Políticas Públicas, Brasília, v.8, n.2, 2018, p.639-659;

SOARES, Fábio Rubens; COELHO, Suani Teixeira. Brazil-WTE Incineration Plant. In: Municipal Solid Waste Energy Conversion in Developing Countries. Amsterdam: Elsevier. COELHO, Suani Teixeira; PEREIRA, Alessandro Sanches; BOUILLE, Daniel Hugo; MANI, Shyamala K.; RECALDE, Marina Yesica; SAVINO, Atilio Armando; STAFFORD, William H.L., 1 ed., 2019, p. 134.

STEHLIK, Petr. Up-to-DataWaste-to-Energy Aproach: From Idea to Industrial Application. Springer: Czech Republic, 2018, p.5.

THEMELIS, Nikolas J., BARRIGA, Maria Elena Diaz, ESTEVEZ, Paula, Et al. Guidebook for theApplication of Waste to Energy Technologies in Latin America and The Caribean. 2013. Disponivel em: < ttp://www.seas.columbia.edu/earth/wtert/pressreleases/ Guidebook_WTE_v5_July25_2013.pdf>. Acesso em 31 de jul. 2019.

UNIÂO EUROPÉIA. Diretiva 2009/28/EC do Conselho. 1999. Disponível em < https:// eur-lex.europa.eu/legal-content/PT/TXT/PDF/?uri=CELEX:31999L0031\&from=FR>. Acesso em 15 de out. 2019;

. Diretiva 2008/98/EC do Parlamento Europeu e do Conselho. 2008. Disponível em: <https://eur-lex.europa.eu/legal-content/PT/TXT/PDF/?uri=CELEX:32008L0098\&from=EN>. Acesso em 15 de out. 2019;

. Diretiva 2000/76/CE do Parlamento Europeu e do Conselho. 2000. Disponível em: <https://publications.europa.eu/pt/publication-detail/-/publication/f735dd50-bee0-43e5-aad7-f6387270dcb9/language-pt>. Acesso em 15 de out. 2019;

Diretiva 2010/75/CE do Parlamento Europeu e do Conselho. 2000. Disponível em: <https://eur-lex.europa.eu/legal-content/PT/TXT/PDF/?uri=CELEX:32010L0075\&from=PT> Acesso em 15 de out. 2019;

YAZBEK, Cristiano Lisboa; FOLLONI, André Parmo. Governança e essencialidade ambiental como fundamentos à aplicaçăo do princípio da seletividade do IPI 2014. Dissertaçāo (Mestrado) - Pontifícia Universidade Católica do Paraná, Curitiba, 2014. Disponível em: http://www.biblioteca.pucpr.br/tede/tde_busca/arquivo.php?codArquivo=2706 Acesso em 22 de jul 2018.

Recebido em: 06 de agosto de 2019. Aprovado em: novembro de 2019. 